\title{
Literasi Informasi untuk Meningkatkan Keterampilan Pencarian Informasi Ilmiah Siswa SMA
}

\author{
Kartika Yuni Purwanti1 ${ }^{*}$, Lisa Virdinarti Putra² ${ }^{2}$ Anni Malihatul Hawa ${ }^{3}$ \\ 1,2,3 Universitas Ngudi Waluyo
}

\section{A R T I C L E I N F O \\ Article history: \\ Received 19 August 2018 \\ Received in revised form \\ 19 September 2018 \\ Accepted 20 Oktober 2018 \\ Available online 24 \\ November 2018}

\section{Kata Kunci:}

literasi informasi,

plagiarism

Keywords:

information literacy,

plagiarism

\begin{abstract}
A B S T R A K
Kegiatan pengabdian ini ditujukan untuk melatih siswa untuk menggunakan informasi secara bertanggung jawab dengan cara mencantumkan asal atau sumber informasi yang dipergunakan, mensitasi atau mengutip informasi tertentu dengan benar, serta menggunakan informasi secara beretika. Metode pelaksanaan yang digunakan adalah metode partisipatif dengan melalui tiga tahap yaitu 1) sosialisasi, 2) pendampingan, 3) monitoring dan evaluasi. Hasil dari pelaksanaan adalah: 1) pemahaman literasi informasi dalam kategori sangat baik. Hal ini ditandai dengan rata-rata persentase indikator ketercapaian sebesar $86 \%$. 2) memperoleh respon positif yang dilihat dari indikator kehadiran peserta mencapai $98 \%$ dari target dan peserta antusias selama mengikuti kegiatan dari awal sampai akhir kegiatan. Kegiatan literasi informasi perlu dilaksanakan secara rutin agar seluruh siswa mampu menelusur dan mengevaluasi informasi dengan baik. Perpustakaan perlu mensosialisasikan kegiatan ini untuk membantu siswa dalam pencarian informasi ilmiah sehingga keterbatasan sumber informasi ilmiah berupa jurnal dapat diatasi dengan situs-situs yang meyediakan jurnal-jurnal ilmiah tak berbayar atau gratis.
\end{abstract}

\section{A B S T R A C T}

This service activity is intended to train students to use information responsibly by including the origin or source of information used, correctly citing or citing certain information, and using information ethically. The implementation method used is a participatory method through three stages, namely 1) socialization, 2) mentoring, 3) monitoring and evaluation. The results of the implementation are: 1) understanding information literacy in a very good category. This is indicated by the average percentage of achievement indicators of $86 \%$. 2) get a positive response seen from the attendance indicator of participants reaching $98 \%$ of the target and enthusiastic participants during the activities from the beginning to the end of the activity. Information literacy activities need to be carried out regularly so that all students are able to track and evaluate information properly. The library needs to socialize this activity to help students in finding scientific information so that the limited source of scientific information in the form of journals can be overcome with sites that provide free or free scientific journals.

\footnotetext{
* Corresponding author.

E-mail addresses: Kartika.yuni92@gmail.com (Kartika Yuni Purwanti), lisavirdinartiputra@gmail.com (Lisa Virdinarti Putra), hawa.anni@gmail.com (Anni Maluhatul Hawa)
} 


\section{Pendahuluan}

Umat manusia dikatakan telah memasuki sebuah era baru yang ditandai dengan adanya lompatan kemajuan teknologi pengetahuan yang luar biasa. Hal ini dapat dilihat dari sedemikian pentingnya pemanfaatan teknologi pengetahuan dalam kehidupan sehari-hari. Maka, tidaklah mengherankan jika masa ini seringkali disebut pula dengan era masyarakat informasi (Webster, 2006). Informasi memegang peranan penting dalam mendukung berbagai aktivitas setiap orang, karena informasi sudah menjadi kebutuhan utama setiap individu, terutama dalam bidang pendidikan dan penelitian (Rufaidah, 2013). Yusuf (2017) mengatakan tidak ada seorang pun di dunia ini yang bias menghitung banyaknya informasi yang pernah dilahirkan karena jumlah informasi yang terus berkembang tak terbatas seiring dengan semakin banyaknya jumlah manusia yang dilahirkan dan semakin banyaknya gagasan manusia yang melahirkan informasi.

Dalam konteks perpustakaan dan informasi, literasi informasi dikaitkan dengan kemampuan mengakses dan memanfaatkan secara benar sejumlah informasi yang ada di internet. Untuk itu, yang perlu diperhatikan oleh pemakai khususnya pemakai perpustakaan sekolah dalam memanfaatkan teknologi internet adalah keterampilan menelusur informasi serta mengetahui strategi penelusuran yang efektif dan efisien (Pendit, 2008). Literasi informasi berhubungan dengan kemampuan dalam menggunakan teknologi informasi akan tetapi dengan kompetensi dan cakupan yang berbeda (Sukaesih, 2013).

Perpustakaan sebagai bagian dari sekolah turut berperan sangat penting dalam mendukung program pembelajaran seumur hidup. Salah satu tugas perpustakaan adalah memberikan pendidikan pemakai serta bimbingan pembaca. Salah satu kegiatan yang dapat dilakukan oleh perpustakaan dalam kegiatan pendidikan pemakai adalah kegiatan literasi informasi.

Kata literasi merupakan kemampuan baca tulis. Ada begitu banyak jenis literasi yang berkembang hingga saat ini, seperti misalnya literasi komputer, literasi media, literasi teknologi, literasi ekonomi, literasi digital (digital literacy), dan lain-lain (Naibaho, 2007; Sulistyo-Basuki, 2013; Bawden, 2008). Dari berbagai jenis literasi tersebut, literasi bisa dimaknai sebagai melek teknologi, melek komputer, melek digital, dan lain sebagainya. Literasi secara luas dimaknai sebagai kemampuan berbahasa mencakup kemampuan menyimak, berbicara, membaca, dan menulis, serta berpikir yang menjadi elemen dalam literasi itu sendiri (Sari, 2017).

Siswa SMA, SMK dan sederajat memang sudah banyak yang melakukan literasi internet, namun tidak menutup pula kemungkinan ada siswa yang sebaliknya, yakni mereka belum literasi internet. Gagasan ini berkaitan erat dengan kelas sosial siswa SMA, SMK dan sederajat sangat beragam, yakni tidak seluruhnya berasal dari kelas sosial atas dan berlatar belakang budaya kota, melainkan banyak pula yang berasal dari kelas sosial bawah dan berlatar belakang budaya desa. Belum terhitung lagi adanya kenyataan bahwa mereka yang literasi internet pun, belum paham betul tentang bagaimana menggunakan media internet secara fungsional dalam konteks memperkaya sumber ilmu secara baik dan benar. Demi kemudahan para siswa seringkali hanya mengkopi paste tugas yang diberikan oleh guru mereka sehingga seringkali dari sekian siswa terdapat tulisan yang sama persis antara satu siswa dengan siswa lainnya.

Kondisi awal pencarian informasi ilmiah di SMAN 1 Getasan dan SMAN 1 Ampel menunjukkan bahwa pemahaman siswa terhadap jurnal ilmiah masih rendah, rata-rata kondisi awal hanya $11 \%$. Beberapa siswa mengenal beberapa jurnal, tetapi ketepatan dalam memilih, menelusur serta mensitasi karya orang lain masih rendah.

Tujuan dari kegiatan ini adalah melatih siswa untuk memformulasikan kebutuhan informasi, memilih dan mengevaluasi informasi secara hati-hati, mampu mengkomunikasikan atau sharing informasi kepada teman-temannya, serta melatih untuk menggunakan informasi secara bertanggung jawab dengan cara mencantumkan asal atau sumber informasi yang dipergunakan, mensitasi atau mengutip informasi tertentu dengan benar, serta menggunakan informasi secara beretika.

\section{Metode}

Sasaran kegiatan pengabdin kepada masyarakat adalah siswa kelas XII SMAN 1 Getasan (31 siswa kelas IPS 1 dan IPS 2) dan SMAN 1 Ampel (25 siswa IPA 1 dan IPA 2). Metode kegiatan yang dilakukan dalam pengabdian masyarakat ini adalah dengan metode partisipatif artinya mitra binaan secara aktif dilibatkan semua dalam semua tahapan kegiatan pengabdian masyarakat ini. Kegiatan ini menggunakan metode pelatihan yang akan dilaksanakan selama 3 (tiga) hari dengan materi pelatihan berupa ceramah, praktek, serta evaluasi yang disajikan secara bersamaan. Setelah kegiatan pelatihan, akan dilanjutkan kegiatan evaluasi sebagai bahan koreksi bagi penyelenggara kegiatan. Hasil evaluasi ini nantinya dapat 
dijadikan sebagai bahan pertimbangan bagi perpustakaan untuk melaksanakan kegiatan serupa terkait dengan kegiatan pendidikan pemakai.

Sarana dan alat yang digunakan adalah materi pelatihan, LCD, rol kabel, labtop, kuota internet/wifi, serta lembar survey literasi informasi. Rancangan evaluasi dari kegiatan ini menekankan pada proses dan hasil. Penilaian proses dilakukan pada saat siswa mendengarkan ceramah sekaligus praktek pelatihan literasi informasi. Melalui pertanyaan dan keseriusan peserta latihan akan diperoleh bagaimana antusiasme dan kebermanfaatan kegiatan ini. Akan dievaluasi juga tentang pengetahuan siswa tentang situs terkait informasi ilmiah di internet.

\section{Hasil dan pembahasan}

Kegiatan pengabdian kepada masyarakat yang telah dilakukan tim pelaksana mendapat respon positif dari kedua mitra yaitu SMAN 1 Getasan dan SMAN 1 Ampel. Hal ini terlihat dari siswa yang antusias mengikuti kegiatan dan hasil kegiatan juga dalam kategori sangat baik. Kegiatan ini dilakukan dengan cara tatap muka selama tiga kali pertemuan dengan durasi 2 jam/pertemuan. Kegiatan pertama yaitu membagikan angket kondisi awal siswa serta sosialisasi literasi informasi. Kegiatan ini dilakukan oleh 3 orang tim pelaksana dengan pokok bahasan yang disampaikan adalah memperkenalkan database berlangganan (berbayar/fee) serta sumber elektronik gratis (free), mengembangkan strategi pencarian informasi serta konsep dan kata-kata kunci, menggunakan alat bantu dan operator pencarian informasi, dan mengenalkan cara mensitasi atau mengutip hasil karya orang lain untuk menghindarkan dari jerat plagiarism.

Kegiatan kedua adalah praktik strategi pencarian informasi. Pelatihan dilakukan dengan metode ceramah dan praktek. Pada saat dijelaskan tentang strategi pencarian informasi, siswa langsung melakukan praktek dengan menggunakan laptop atau PC yang dibawa oleh masing-masing siswa. Kegiatan praktik ini berakhir dengan harapan agar semangat menulis karya ilmiah oleh siswa tetap dijaga sehingga apa yang diperoleh selama pelatihan dilatih terus dalam penulisan tugas-tugas di bangku sekolah sehingga mereka akan menjadi manusia yang mampu menjunjung tinggi etika ilmiah dengan mengedepankan kejujuran.

Kegiatan ketiga adalah monitoring dan evaluasi (monev) yaitu mem-follow up dari kedua kegiatan yang telah dilakukan sebelumnya. Pelatihan literasi informasi secara umum telah berlangsung baik dan lancar. Tingkat penyerapan siswa terhadap pemaparan dan praktek yang diberikan oleh kedua pelaksana cukup baik dilihat dari antusiasme peserta dalam bertanya terkait materi yang diberikan oleh pelaksana. Kasus-kasus yang dikemukakan oleh pelaksana ditanggapi dengan menanyakan kembali hal-hal terkait penulisan ilmiah serta penelusuran ilmiah yang selama ini biasa dilakukan oleh para peserta.

Hasil dari kegiatan ini diharapkan dapat membekali siswa dengan kemampuan memanfaatkan dan menggunakan informasi secara efektif dan etis untuk kebutuhan informasi mereka. Untuk itu, setelah mengikuti pelatihan literasi informasi, siswa diharapkan untuk mempraktekkan cara penelusuran informasi ilmiah yang sudah dipraktekkan. Untuk keperluan evaluasi kegiatan tersebut, maka setiap siswa diberikan semacam laporan pribadi yang berisi pertanyaan terbuka terkait penelusuran sumber ilmiah di internet.

Hasil ketiga kegiatan yang telah dilakukan menunjukkan peningkatan pemahaman yang dimiliki peserta kegiatan yang berjumlah 56 orang. Peningkatan tersebut dapat terlihat pada persentase pemahaman sebelum dilakukannya kegiatan pengabdian kepada masyarakat dan setelah dilakukannya kegiatan pengabian kepada masyarakat yang dapat terlihat pada Gambar 1.

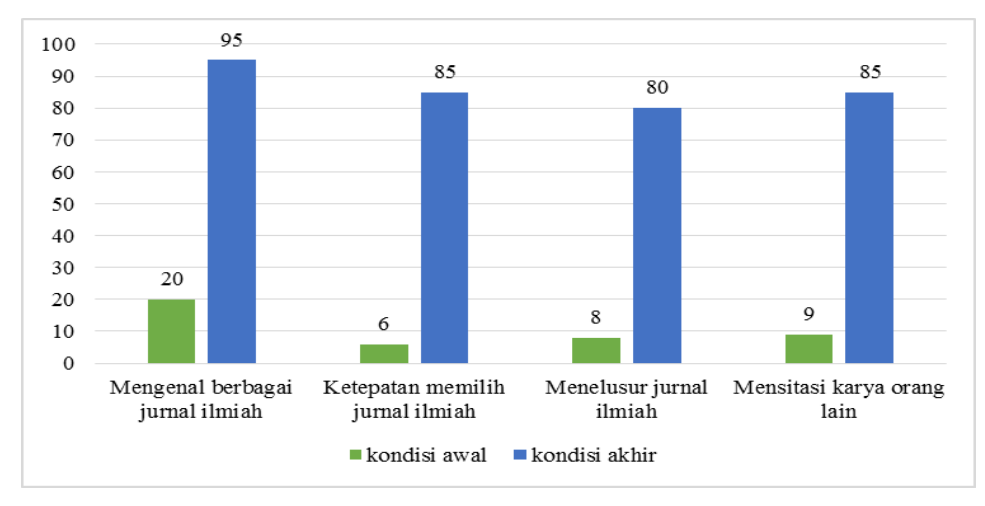

Gambar 1. Peningkatan Pencarian Informasi Ilmiah 
Berdasarkan Gambar 2, peserta kegiatan telah mengalami peningkatan pencarian informasi ilmiah dengan rata-rata 86\%, yaitu mengenal berbagai jurnal ilmiah 95\%, ketepatan memilih jurnal ilmiah sebesar 85\%, menelusur jurnal ilmiah sebesar 80\%, mensitasi karya orang lain 85\%. Oleh karena itu, hasil kegiatan literasi informasi ini dapat dikatakan berhasil dalam kategori sangat baik. Hasil kegiatan ini diharapkan dapat digunakan siswa dalam menghargai karya orang lain untuk mencegah terjadinya plagiarism.

Kendala yang ditemui dalam kegiatan ini adalah kurangnya fasilitas berupa komputer atau laptop bagi siswa untuk melaksanakan penelusuran langsung di tempat pelatihan sehingga laporan keberhasilan penelusuran informasi ilmiah oleh siswa tidak dapat diterima 100\%. Apabila di kemudian hari, ada pihakpihak yang akan melakukan kegiatan yang sama agar sedini mungkin mempersiapkan fasilitas berupa komputer atau laptop.

Selama kegiatan pengabdian di SMAN 1 Getasan dan SMAN 1 Ampel, siswa memiliki banyak manfaat, diantaranya dengan memiliki literasi informasi memiliki kemudahan-kemudahan dalam melakukan berbagai hal yang berhubungan dengan kegiatan informasi. Siswa tidak akan tergantung kepada guru karena dapat belajar secara mandiri dengan kemampuan literasi informasi yang dimiliki. Hal ini dapat dilihat dari penampilan dan kegiatan mereka di lingkungan belajar. Siswa yang literat juga akan berusaha belajar mengenai berbagai sumber daya informasi dan cara penggunaan sumber-sumber informasi.

\section{Simpulan dan saran}

Berdasarkan uraian pada hasil dan pembahasan di atas, maka dapat disimpulkan sebagai berikut : 1) Pelaksanaan kegiatan literasi informasi meningkatkan pemahaman dalam penelusuran informasi ilmiah dengan rata-rata 86\%, yaitu mengenal berbagai jurnal ilmiah 95\%, ketepatan memilih jurnal ilmiah sebesar 85\%, menelusur jurnal ilmiah sebesar 80\%, dan mensitasi karya orang lain 85\%. Kegiatan ini tergolong dalam kategori sangat baik dengan rata-rata 86\%, dan 2) Tanggapan positif dari siswa SMAN 1 Getasan maupun SMAN 1 Ampel terhadap pelaksanaan kegiatan pengabdian masyarakat ini sangat baik. Hal ini dapat dilihat dari indikator kehadiran peserta mencapai 98\% dari target, dan selama kegiatan berlangsung peserta sangat antusias mengikuti kegiatan dari awal sampai akhir kegitan.

Dari hasil evaluasi yang diperoleh melalui angket yang diberikan pada siswa, ada beberapa saran yang bisa dilaksanakan oleh pihak sekolah, yaitu: 1) Kegiatan literasi informasi perlu dilaksanakan secara rutin agar seluruh siswa mampu menelusur dan mengevaluasi informasi dengan baik. 2) Perpustakaan sebagai jantungnya pengetahuan perlu mensosialisasikan kegiatan ini untuk membantu siswa dalam pencarian informasi ilmiah sehingga keterbatasan sumber informasi ilmiah berupa jurnal dapat diatasi dengan situs-situs yang meyediakan jurnal-jurnal ilmiah tak berbayar atau gratis, 3) Pihak sekolah dapat mencanangkan kegiatan literasi informasi sebagai kegiatan wajib bagi siswa baru maupun lama sehingga mereka semua dapat mengakses informasi yang tidak tersedia di perpustakaan bagi keluasaan ilmu pengetahuan mereka. Sebagai kegiatan wajib, maka siswa harus memiliki sertifikat sebagai tanda sudah mengikuti kegiatan literasi informasi

\section{Daftar Rujukan}

Ariani, L.P.S., dkk. 2014. Pelatihan Literasi Informasi untuk Meningkatkan Keterampilan Mahasiswa Universitas Pendidikan Ganesha (Undiksha) dalam Pencarian Informasi Ilmiah di Era Digital. Laporan Akhir Pengabdian pada Masyarakat: Lembaga Penelitian dan Pengabdian kepada Masyarakat Univesitas Pendidikan Ganesha (Undiksha).

Ariyani, Luh Putu Sri, I Gusti Made Arya Suta Wirawan. 2017. Peningkatan Minat Baca Dan Literasi Informasi Masyarakat Melalui Program Unggulan Perpustakaan Umum Di Bali. SEMINAR NASIONAL RISET INOVATIF.

Batubara, Abdul Karim. 2015. Literasi Informasi Di Perpustakaan. Jurnal Iqra' Volume 09 No.01.

Bawden, D. 2008. Origins and concepts of digital literacy. Dalam C. Lankshear\&M. Knobel (eds). Digital literacies : concepts, policies, and paradoxes. Pp:15-32. New Yok: Peter Lang.

Delfi, Syofia. 2013. “Kegiatan Membaca sebagai Penerapan Literasi Mahasiswa Prodi Bahasa Inggris FKIP Universitas Riau". http://ejournal.unri.ac.id/index.php/JB/a rticle/view/1118. Diakses pada 10 Februari 2017. 
Gipayana, Muhana. 2014. "Pengajaran Literasi dan Penilaian Portofolio dalam Konteks Pembelajaran Menulis di Sekolah Dasar". Jurnal Ilmu Pendidikan. Volume 11 Nomor 1.

Kurnianingsih, Indah, Rosini, Nita Ismayati. 2017. Upaya Peningkatan Kemampuan Literasi Digital bagi Tenaga Perpustakaan Sekolah dan Guru di Wilayah Jakarta Pusat Melalui Pelatihan Literasi Informasi. Jurnal Pengabdian kepada Masyarakat, Vol. 3, No. 1, Hal 61 - 76 DOI: Tersedia online di http://jurnal.ugm.ac.id/jpkm.

Kurniawan, Komang Indra, Sang Ayu Putu Sriasih, I Gede Nurjaya. 2017. Implementasi Program Gerakan Literasi Sekolah (Gls) Di Sma Negeri 1 Singaraja. e-Journal Jurusan Pendidikan Bahasa dan Sastra Indonesia Volume: 7 No: 2

Marseno, Ronald, Wisnu Ananta Kusuma, Abdul Rahman Saleh. 2016. Identifikasi Literasi Informasi dalam Rangka pengembangan kurikulum di sekolah dasar. Jurnal Pustakawan Indonesia Volume 13 Nomor 1 .

Naibaho, Clara. 2007. Menciptakan generasi Literat Melalui Perpustakaan. Diunduh pada tanggal 4 Februari 2018 pada http://eprints.rclis.org/12549/1/Menciptakan_Generasi_Literat_Melalui_Perpustakaan.pdf

Pendit, Putu Laxman. 2008. Perpustakaan Digital dari A sampai Z. Jakarta: Cita Karyakarsa Mandiri.

Pendit, Putu Laxman. 2005. Perpustaaan Digital: Perspektif Perpustakaan Perguruan Tinggi Indonesia. Depok: Perpustakaan UI.

Rufaidah, Vivit Wardah. 2013. Literasi Informasi Pustakawan/Pengelola Perpustakaan Lingkup Kementerian Pertanian (Information Literacy Of Librarians/Library Managers Within The Ministry Of Agriculture). J. Perpus. Pert. Vol. 22 No. 1 Hal. 16-23

Sari, Ni Putu Arista, M.G. Rini Kristiantari, I.G.A.Agung Sri Asri. 2017. Pengaruh Model Pembelajaran Literasi Sebagai Budaya Sekolah Terhadap Penguasaan Kompetensi Pengetahuan Ips Siswa Kelas V. e-Journal PGSD Universitas Pendidikan Ganesha Mimbar PGSD Vol: 5 No: 2

Sukaesih, Asep Saeful Rohman. 2013, Literasi Informasi Pustakawan: Studi Kasus di Universitas Padjadjaran . Jurnal Kajian Informasi \& Perpustakaan Vol.1/No.1, hlm 61-72.

Sulistyo-Basuki. 2013. Literasi Informasi dan literasi Digital dalam http://sulistyobasuki.wordpress.com/2013/03/25/literasiinformasi-dan-literasi-digital/ diunduh pada tgl 15 Februari 2018.

Yusup, Pawit M., Encang Saepudin. 2017. Praktik Literasi Informasi Dalam Proses Pembelajaran Sepanjang Hayat (Information Literacy Practices In The Process Of Lifelong Learning). JURNAL Kajian Informasi \& Perpustakaan, Vol.5/No.1, Juni 2017, hlm 79-94 